\title{
Possible Toxic Effects of Normal and Diabetic Patient Serum on Pancreatic B-Cells
}

\author{
A. Lernmark ${ }^{1}$, J. Sehlin ${ }^{1}$, I.-B. Täljedal ${ }^{1}$, H. Kromann ${ }^{2}$, and J. Nerup ${ }^{2}$ \\ ${ }^{1}$ Department of Histology, University of Umeå, Umeå, Sweden, and ${ }^{2}$ Steno Memorial Hospital, Gentofte, Copenhagen, Denmark
}

\begin{abstract}
Summary. Serum from normal blood-donors and juvenile diabetic patients inhibited $\mathrm{Rb}^{+}$accumulation and stimulated release of ${ }^{51} \mathrm{Cr}$ and insulin in suspensions of dispersed pancreatic islet cells prepared from $a b / o b$ mouse islets, which are rich in B-cells. The effects indicate the presence of a Bcytotoxic factor in human serum. Serum from mouse and fetal calf also inhibited the islet cell accumulation of $\mathrm{Rb}^{+}$. Toxicity was not suppressed by treating serum with protein A-Sepharose and did not correlate with islet cell binding of fluorescent antibodies to human immunoglobulin. Whereas all sera inhibited $\mathrm{Rb}^{+}$accumulation, 3 of 6 diabetic patient sera, but no blood-donor serum, made the cells fluoresce on exposure to the fluorescent antibodies. Supporting a dependence on complement, toxicity remained after dialysis, but was destroyed by treating serum with zymosan-A or heating at $56^{\circ}$ for $30 \mathrm{~min}$.
\end{abstract}

Key words: Diabetes mellitus, pancreatic B-cells, serum cytotoxicity, serum complement, islet cell antibodies, rubidium accumulation, insulin release, autoimmunity.

Five types of phenomena suggest that juvenile diabetes mellitus results from toxic influences on the pancreatic B-cells: i) inflammation and lymphocyte infiltration of islets in recently diagnosed patients $[1,2]$, ii) inhibited migration of patient's leucocytes on exposure to pancreas extracts $[3,4]$, iii) correlation between the incidence of virus infections and the detection of new diabetic cases [5, 6], iv) association of diabetes with histocompatibility antigens that may signify a disposition to increased virus susceptibility or adverse immunological responses [7,
8], and v) binding of fluorescent antibodies against human immunoglobulin to islet sections treated with patient serum [9-11].

Model experiments with alloxan showed $\mathrm{Rb}^{+} \mathrm{ac}-$ cumulation in islet cells to be a sensitive parameter of at least one type of diabetogenic damage to $\mathrm{B}$-cells $[12,13]$. We therefore investigated the influence of diabetic patient serum on the B-cell accumulation of $\mathrm{Rb}^{+}$. These experiments led to the unexpected finding that serum in general is toxic to B-cells. Since this discovery may have important implications for the understanding of islet function and diabetes, a first characterization of the B-cytotoxic serum effect is reported.

\section{Materials and Methods}

${ }^{86} \mathrm{Rb}$ Accumulation and Release of ${ }^{51} \mathrm{Cr}$ and Insulin

Suspensions of $o b / o b$ mouse islet cells $[14,15]$ were incubated with or without serum in tissue culture medium 199 [16] supplemented with $5 \mathrm{mmol} / \mathrm{l} \mathrm{D}$ glucose, $10 \mathrm{~g} / \mathrm{l}$ human serum albumin and 20 $\mathrm{mmol} / \mathrm{l} \quad N$-hydroxyethylpiperazine- $N$ '-2-ethanesulphonic acid and equilibrated with ambient air (TCM). Islet cell accumulation of ${ }^{86} \mathrm{Rb}^{+}$at $37^{\circ}$ was measured as previously [15], except that sucrose [17] instead of inulin [15] was used as an extracellular water marker. In brief, cells were incubated with $28 \mu \mathrm{mol} / 1{ }^{86} \mathrm{RbCl}(0.7 \mathrm{Ci} / \mathrm{mmol})$ and $8 \mu \mathrm{mol} / 1$ $\left(6,6,-{ }^{3} \mathrm{H}_{2}\right)$ sucrose $(2 \mathrm{Ci} / \mathrm{mmol})$ in $300 \mu \mathrm{TCM}$ for $2 \mathrm{~h}$, centrifuged through oil, and analyzed by twochannel liquid-scintillation counting.

To study release of ${ }^{51} \mathrm{Cr}$ [18], cells were incubated for $60 \mathrm{~min}$ at $37^{\circ}$ in $1 \mathrm{ml}$ TCM supplemented with $0.4-0.9 \mu \mathrm{mol} / 1 \mathrm{Na}_{2}{ }^{51} \mathrm{CrO}_{4}(57 \mathrm{Ci} / \mathrm{mmol})$. They were then washed with $10 \mathrm{ml}$ TCM, centrifuged for 
$5 \mathrm{~min}(50 \mathrm{~g})$, and incubated for $2 \mathrm{~h}$ in $300 \mu \mathrm{l}$ nonradioactive TCM containing 25 or $50 \%$ blood-donor serum, or blood-donor serum that had first been held at $56^{\circ}$ for $30 \mathrm{~min}$; control cells were incubated in serum-free TCM. Incubation was ended by centrifuging through oil [15], and ${ }^{51} \mathrm{Cr}$ in medium and cell pellet measured.

To study release of insulin, cells were incubated at $37^{\circ}$ for 30,60 or $120 \mathrm{~min}$ in $100 \mu \mathrm{l} \mathrm{TCM} \mathrm{(5}$ mmol/1 glucose) containing no serum, $75 \%$ blooddonor serum, or $75 \%$ blood-donor serum that had first been held at $56^{\circ}$ for $30 \mathrm{~min}$. After incubation, $10 \mathrm{ml}$ TCM was added, the cells were centrifuged for $5 \mathrm{~min}(50 \mathrm{~g})$, and insulin in medium and cell pellet radioimmunologically assayed with crystalline mouse insulin as reference.

\section{Immunofluorescent Staining}

Cells incubated at $30^{\circ}$ for $30 \mathrm{~min}$ in $100 \mu \mathrm{l} \mathrm{TCM}$ with or without serum were diluted with $10 \mathrm{ml}$ TCM, centrifuged (50 g, $5 \mathrm{~min})$, resuspended and then incubated for $1 \mathrm{~h}$ at $30^{\circ}$ with fluoresceinisothiocyanate-conjugated antibodies to human immunoglobulin (commercial antibodies diluted 1:10 with TCM in $100 \mu \mathrm{l}$ final volume). After centrifugation as above and resuspension in TCM, cells were inspected in a fluorescence microscope equipped with a Zeiss epicondensor. Cells were also centrifuged in glass capillaries $(10 \mu \mathrm{l}$ disposable pipettes from Drummond Scientific Co., Broomall, Pa.); after mounting capillaries in immersion oil between object and cover glasses, the pellet fluorescence was measured under incident excitation [10]. TCM, antibodies and serum used in fluorescent staining experiments were Millipore-filtered $(0.45 \mu \mathrm{m}$ pore) .

\section{Collection and Treatment of Blood Serum}

Normal serum was from 15 healthy blood-donors in Umeå and from mice and guinea-pigs of Umeå colonies. Serum was also obtained from 5 male and 1 female juvenile diabetic patients at the Steno Memorial Hospital, Denmark. Three of these patients had sera with islet cell antibodies, as diagnosed by indirect fluorescent staining of islet sections of human blood-group 0 pancreatic glands [11]. Patients were 5-28 years of age and had not been treated with insulin. All sera were kept at $-90^{\circ}$ until used within a year. Glucose was determined in pooled normal sera and adjusted to a final concentration of $5 \mathrm{mmol} / 1$.

To inactivate the third complement factor in some experiments, $500 \mu \mathrm{l}$ of serum was incubated with $10 \mathrm{mg}$ of zymosan- $\mathrm{A}$ at $37^{\circ}$ for $2 \mathrm{~h}$, followed by centrifugation to remove insoluble zymosan; analogous treatment of TCM with zymosan-A had no effect on the islet cell uptake of $\mathrm{Rb}^{+}$. In other experiments we attempted to remove $\mathrm{IgG}$ by shaking $2 \mathrm{ml}$ of serum at $4^{\circ}$ for $2 \mathrm{~h}$ with $1 \mathrm{ml}$ of protein Asepharose gel that had first been washed 4 times with several volumes of $0.1 \mathrm{~mol} / \mathrm{l} \mathrm{NaCl}$ in $10 \mathrm{mmol} / \mathrm{l}$ $N$-hydroxyethylpiperazine- $N$ '-2-ethanesulphonic

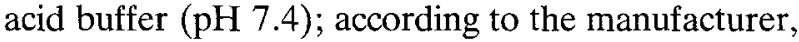
protein-A-sepharose binds $25 \mathrm{mg}$ of $\mathrm{IgG} / \mathrm{ml}$ gel. Before the treated serum was added to TCM and cells, protein A-sepharose was removed by centrifugation; analogous treatment of TCM with protein A-sepharose had only a marginal effect on $\mathrm{Rb}^{+} \mathrm{ac}$ cumulation (uptake was $88 \pm 5 \%$ of that in cells incubated in untreated TCM).

\section{Chemicals}

${ }^{86} \mathrm{RbCl}$ and $\left(6,6^{\prime}-{ }^{3} \mathrm{H}_{2}\right)$ sucrose were from the Radiochemical Centre, Amersham, England; $\mathrm{Na}_{2}{ }^{51} \mathrm{CrO}_{4}$ from New England Nuclear, Boston, Mass.; Sepharose-linked protein A of Staphylococcus aureus (Cl-4 B) from Pharmacia Fine Chemicals, Uppsala, Sweden; zymosan-A from Sigma Chemical Co., St. Louis, Mo.; fluoresceinisothiocyanate-conjugated rabbit antibodies to whole human immunoglobulin from Miles Laboratories Inc., Elkhart, Ind.; fetal calf serum and tissue culture medium 199 from the National Bacteriological Laboratories, Stockholm, Sweden, and human serum albumin from $A B$ Kabi, Stockholm, Sweden.

\section{Results}

\section{Effects of Serum on $\mathrm{Rb}^{+}$Accumulation by Islet Cells}

Cells of intact [17] or broken [15] islets accumulate $\mathrm{Rb}^{+}$when incubated in the absence of serum. Figure 1 shows that $10 \%$ serum from normal blooddonors reduced the amount of $\mathrm{Rb}^{+}$appearing in the cell pellet by about one-half; $50 \%$ serum was completely inhibitory. Sera from mouse, guinea-pig, fetal calf, or newly diagnosed juvenile diabetic patients were also inhibitory, although species differences exist in the dose-response relationship (Fig. 1).

The inhibitory effect of serum on $\mathrm{Rb}^{+}$accumulation was reproduced with plasma (Table 1). It persisted after dialysis (Fig. 1) or treatment of serum with protein A-sepharose (Table 1). Heating at $56^{\circ}$ for $30 \mathrm{~min}$ virtually abolished the effect of human serum or plasma and partially diminished that of 


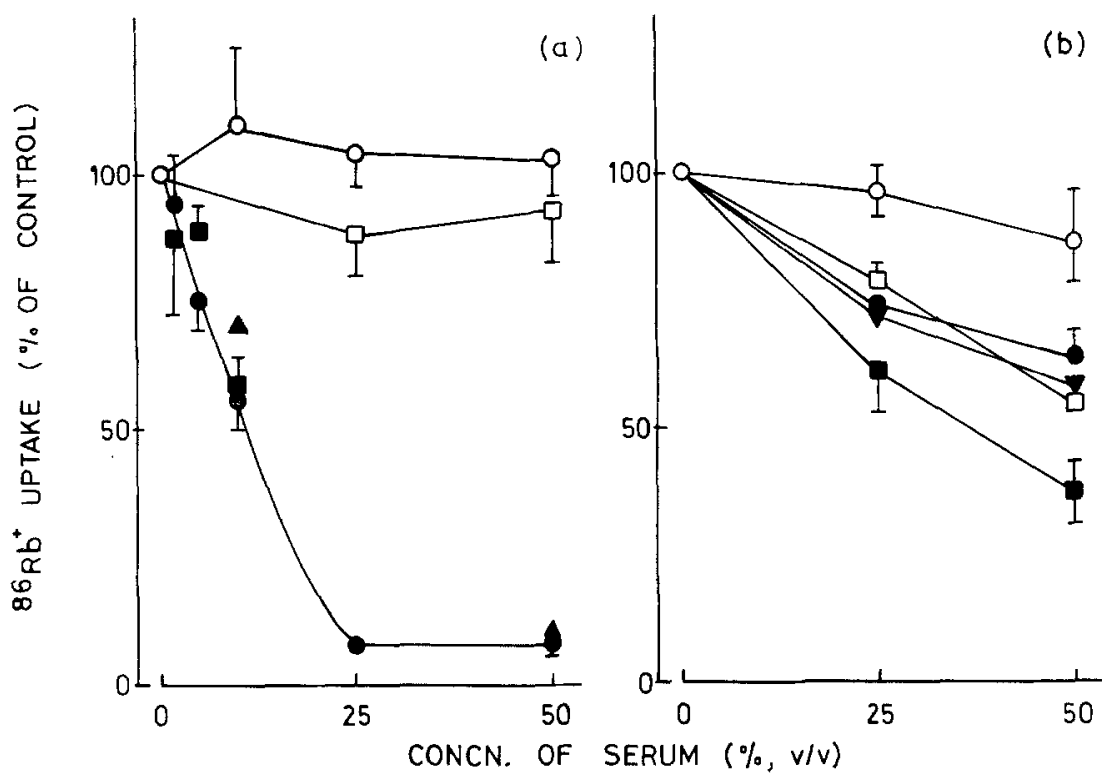

Fig. 1. Effect of serum on $\mathbf{R b}^{+}$accumulation by islet cells. In each experiment cells were incubated in TCM as well as in TCM mixed with serum as indicated. Cellular uptake of $\mathrm{Rb}^{+}$is expressed in percent of that in control cells not exposed to serum. Solid symbois refer to serum that had not been heated, open symbols to serum that had first been held at $56^{\circ}$ for 30 min. The left panel a summarizes 2-12 experiments with normal human blood-donor serum $(\bullet, 0)$, diabetic patient serum $(\boldsymbol{\square}, \square)$ and blood-donor serum that had been dialyzed overnight at $4^{\circ}$ against a 2000 -fold excess of TCM $(\mathbf{\Delta})$. SEM is indicated for values based on more than 2 experiments. Diabetic patient sera were tested individually in 5-6 experiments. Blood-donor sera were tested individually (2-7 experiments) as well as after pooling sera from different donors (4-6 experiments). The right panel $\mathbf{b}$ summarizes 3 or 4 experiments with serum from fetal calf ( $\boldsymbol{\omega}$, $\square)$, guinea-pig $(\boldsymbol{\nabla})$, and $o b / o b$ mice $(\bullet, 0)$

mouse or fetal calf serum. Treatment of serum with zymosan- $\mathrm{A}$ also prevented the inhibition of $\mathrm{Rb}^{+}$accumulation (Table 1). A mixture of $50 \%$ heat-inactivated serum and $5 \%$ non-inactivated serum did not inhibit $\mathrm{Rb}^{+}$accumulation much more than $5 \%$ non-inactivated serum alone (Table 1). The effect of serum was not due to albumin, since the $\mathrm{Rb}^{+}$accumulation was $100 \%, 106 \%$, or $108 \%$ when serum-free TCM contained crystalline human serum albumin at the concentration of 1,10 , or $20 \mathrm{~g} / 1$ (mean values of 2 experiments).

\section{Effects of Serum on the Release of ${ }^{51} \mathrm{Cr}$ and Insulin from Islet Cells}

Human serum induced insulin release (Fig. 2) as well as release of ${ }^{51} \mathrm{Cr}$ from $\mathrm{Na}_{2}{ }^{51} \mathrm{CrO}_{4}$-labelled cells (Fig. 3); mild heating $\left(56^{\circ}, 30 \mathrm{~min}\right)$ of serum inhibited these effects (Figs. 2 and 3). Incubation with serum had no demonstrable effect on the sedimentation of DNA during low-speed (50 g, $5 \mathrm{~min}$ ) centrifugation of cells (not shown).

\section{Staining of Serum-Treated Islet Cells for Antibody-Like Material}

Incubating cells with blood-donor sera or sera from 3 of the diabetic patients did not result in a positive
Table 1. Effect of plasma or modified serum on $\mathrm{Rb}^{+}$accumulation in islet cells

\begin{tabular}{lc}
\hline Addition to TCM & $\begin{array}{l}\mathrm{Rb}^{+} \text {accumulation } \\
\text { (\% of accumu- } \\
\text { lation in } \\
\text { TCM alone) }\end{array}$ \\
\hline None & 100 \\
$25 \%$ Plasma & $19 \pm 6(3)$ \\
$50 \%$ Plasma & $12 \pm 3(3)$ \\
$25 \%$ Plasma held at $56^{\circ}$ for 30 min & $86 \pm 8(3)$ \\
$50 \%$ Plasma held at $56^{\circ}$ for 30 min & $82 \pm 10(3)$ \\
$5 \%$ Serum & $76 \pm 14(3)$ \\
$50 \%$ Serum held at $56^{\circ}$ for 30 min & $79 \pm 3(3)$ \\
$5 \%$ Serum plus $50 \%$ serum held at $56^{\circ}$ & $55 \pm 9(3)$ \\
$10 \%$ Serum & $36 \pm 7(3)$ \\
$10 \%$ Serum treated with zymosan-A & $115 \pm 14(4)$ \\
$25 \%$ Serum treated with protein A-sepharose & $35 \pm 15(4)$
\end{tabular}

Parallel incubations were performed in TCM alone and in TCM supplemented as indicated. Serum was pooled from several healthy blood-donors; heparin plasma was from one donor. Results are given as mean values \pm SEM of the numbers of experiments stated in parentheses; each experiment was performed with a separate preparation of islet cells on a separate day and is not included in Figure 1

immunofluorescent staining of the cell surfaces for immunoglobulin. Sera from the remaining 3 patients made the surface of islet cells fluoresce on exposure to the fluoresceinisothiocyanate-conjugated immunoglobulin antibodies (Fig. 4a/b). A ringshaped 


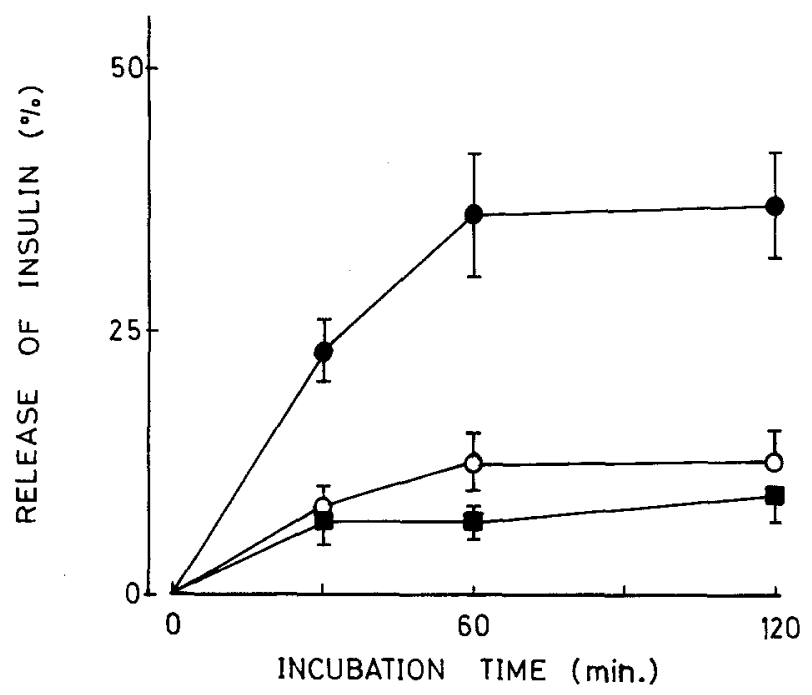

Fig. 2. Percentage release of insulin from islet cells incubated without serum ( $)$, with $75 \%$ blood-donor serum ( $)$, or with $75 \%$ blood-donor serum that had first been held at $56^{\circ}$ for 30 min $(O)$. Mean values \pm SEM of 6 experiments with serum pooled from 6 blood-donors

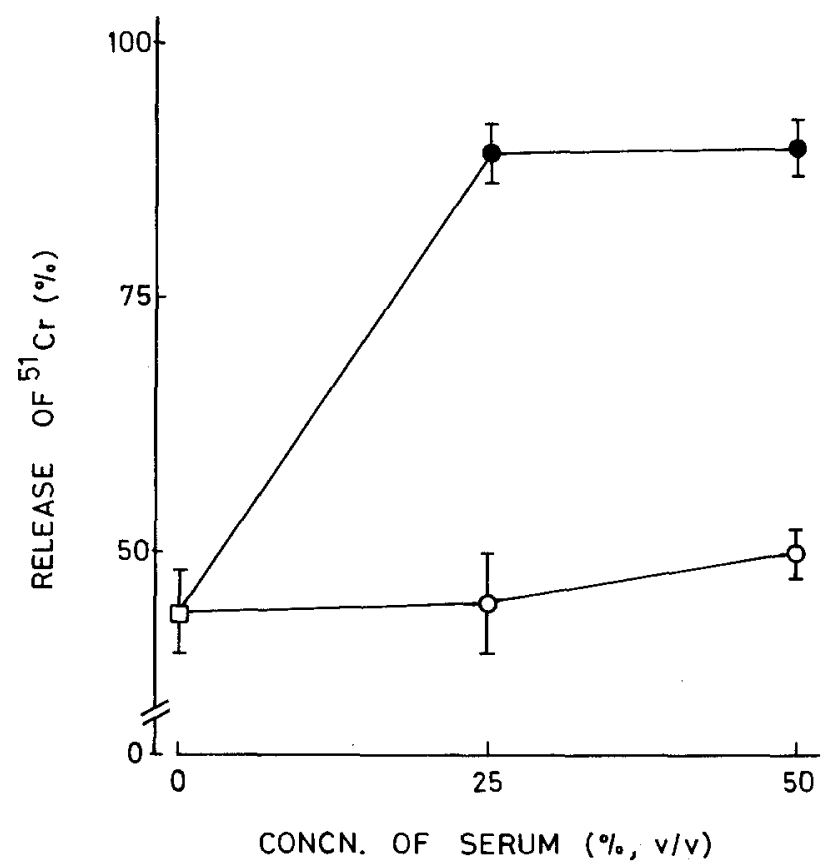

Fig. 3. Percentage release of ${ }^{51} \mathrm{Cr}$ from islet cells exposed for $2 \mathrm{~h}$ to 25 or $50 \%$ blood-donor serum $(\bullet)$, or blood-donor serum that had first been held at $56^{\circ}$ for $30 \mathrm{~min}(0)$. Mean values \pm SEM of 6 experiments with serum pooled from 6 blood-donors
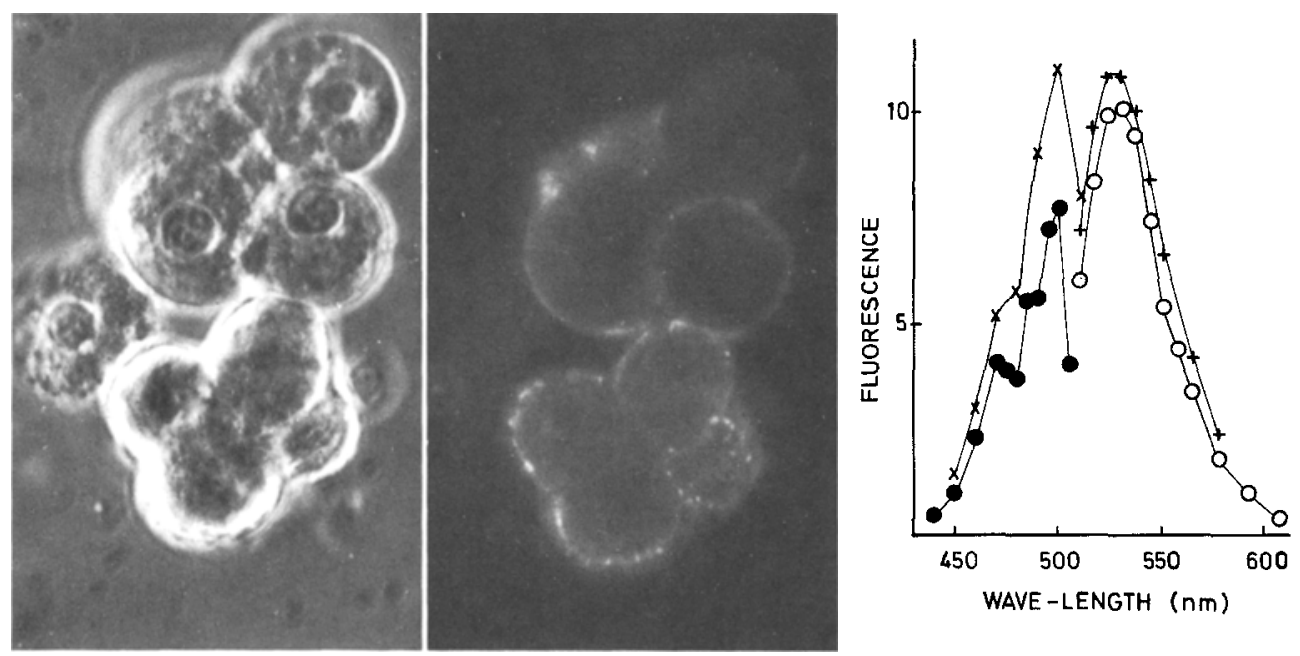

Fig. 4. Immunofluorescent staining of intact islet cells with fluoresceinisothiocyanate-conjugated antibodies to whole human immunoglobulin. Before being exposed to fluorescent antibodies, cells were incubated with $75 \%$ serum from a juvenile diabetic patient. A phase contrast micrograph of some cells is shown to the left $(1280 \times)$; their appearance in the fluorescence microscope is shown in the middle. A centrifuged pellet of cells from the same suspension was analyzed in the microscope fluorimeter and exhibited the excitation ( $; 530$ $\mathrm{nm}$ emission) and emission $(0 ; 480 \mathrm{~nm}$ excitation) spectra shown to the right; cells exposed to fluorescent antibodies without prior treatment with serum were used as blanks. Parallel incubation of cells with normal blood-donor serum did not result in any measurable fluorescence spectrum; such cells did not differ from the blanks. Excitation (x;530 nm emission) and emission ( $+; 490 \mathrm{~nm}$ excitation) spectra of fluoresceinisothiocyanate in buffer were also taken with the microscope fluorimeter. Spectra are uncorrected and expressed in arbitrary units 
staining occurred whether or not serum had first been held at $56^{\circ}$ for $30 \mathrm{~min}$.

The fluorescence of pelleted cells was measured by microscope fluorimetry (Table 2). Non-specific adsorption of antibodies occurred as shown by incubations in absence of serum. Cells incubated with $75 \%$ diabetic patient serum showed the highest mean value; the difference from $7.5 \%$ diabetic serum has a chance probability of less than $10 \%$ (two-tailed $t$ test on paired data). Analysis of individual data revealed a correlation between values measured with or without exposure to serum, probably reflecting between-experiment variations in non-specific adsorption of fluorescent antibodies. The regression of fluorescence after treatment with serum on that after treatment with fluoresceinisothiocyanate-conjugated antibodies alone did not differ significantly in slope or height between blooddonor and diabetic patient serum. Regression analysis showed that the fluorescence induced by one patient's serum (186 arbitrary units) deviated significantly from the value predicted by regression in the combined blood-donor and diabetic group ( $P$ $<0.01 ; t$ test with correction of $d$.f. for non-random selection of deviating value). This diabetic patient's serum also gave the most prominent impression of ring-shaped staining on visual inspection of cells (Fig. $4 \mathrm{a}, \mathrm{b}$ ). This serum did not have an extraordinarily great effect on $\mathrm{Rb}^{+}$accumulation and was negative when tested for islet cell antibodies with the aid of frozen sections of human pancreas [11]; conversely, one of the 3 sera giving a negative reaction with human pancreas was positive when tested here for immunofluorescent staining of viable mouse B-cells. That the fluorescence seen and measured was due to fluoresceinisothiocyanate-conjugated antibodies is evident from the spectra observed in the microscope fluorimeter (Fig. $4 \mathrm{c}$ ).

\section{Discussion}

The results leave no doubt that mouse B-cells are adversely affected by serum. Drastic inhibition of $\mathrm{Rb}^{+}$accumulation has previously been observed only in response to chloromercuribenzene- $p$-sulphonic acid, which increases B-cell permeability to cations $[17,21]$, or the established B-cytotoxic and diabetogenic compound, alloxan [12]. Enhancement of ${ }^{51} \mathrm{Cr}$ release in other cells parallels uptake of Trypan Blue and is recognized as diagnostic of decreased cell viability [18]. The serum-induced release of insulin may be leakage from damaged cells or an activation of the secretory apparatus due to altered transmembrane cationic conditions; an initial en-
Table 2. Measurements of fluorescence from immunohistochemically stained islet cells

\begin{tabular}{|c|c|c|}
\hline $\begin{array}{l}\text { Serum during } \\
\text { pretreatment }\end{array}$ & 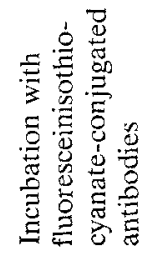 & 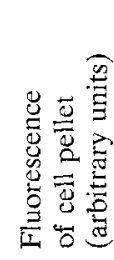 \\
\hline None & No & $27 \pm 4$ \\
\hline None & Yes & $63 \pm 6$ \\
\hline $75 \%$ Blood-donor serum & Yes & $72 \pm 11$ \\
\hline 75\% Diabetic patient serum & Yes & $98 \pm 21$ \\
\hline $7.5 \%$ Diabetic patient serum & Yes & $65 \pm 7$ \\
\hline
\end{tabular}

After incubation under conditions indicated, cells were pelleted in glass capillaries and the pellet fluorescence emitted at $530 \mathrm{~nm}$ measured with $480 \mathrm{~nm}$ excitation wave-length. Mean values \pm SEM of experiments with individual sera from 6 different blood-donors and 6 diabetic patients are given. Two concentrations of diabetic patient serum $(75 \%$ and $7.5 \%)$ were tested in each experiment. The mean \pm SEM of the differences in fluorescence obtained with these two concentrations are shown in the bottom row. The arbitrary unit of fluorescence is proportional to the microscope fluorimeter readings

hancement of insulin release has been observed in response to both organic mercurials [22] and alloxan [23], although both compounds are ultimately lethal to the B-cells.

It is not known whether human B-cells are as sensitive as mouse B-cells to the toxic action of serum. An entirely different behaviour of human B-cells is not to be expected, however, since human and mouse B-cells are morphologically and physiologically very similar. The results with mouse serum show that serum and islets need not be from different species for the B-cytotoxic effect to occur.

It seems important to ask whether B-cells can be exposed to the toxic serum factor in vivo. The toxicity of serum was not lost during dialysis, so the responsible factor is not a small molecule. Since islet inflammation and interstitial pancreas fibrosis have been observed in recently diagnosed patients $[1,2$, 4], onset of juvenile diabetes may well be associated with extravasation of serum factors in the islets. Insulitis in children dying with Coxsackie B virus infection and in virus-infected mice $[4,24]$ indicates that viruses may induce islet inflammation. The islet morphology in mice immunized with homologous islet extracts suggests the possibility of autoimmune inflammatory reactions [25]; it is not known, however, whether the islet cell antibodies described in diabetic patients [9-11] are secondary to islet damage or of other, say virus-mediated, cause [26]. 
Whatever the primary cause of islet inflammation, the present results suggest that activation of a physiological, but potentially toxic, serum factor could perhaps be sufficient to cause the B-cell damage resulting in diabetes. Whether this proposal is of mere theoretical interest or covers the real situation in vivo cannot, of course, be decided on the basis of in vitro experiments alone.

Experiments were performed to test whether the toxic serum factor relates to the immunological system. Attempts to demonstrate an involvement of IgG immunoglobulins failed, since toxicity persisted after treating serum with protein A-Sepharose. Moreover, the toxic effect did not correlate with the islet cell binding of fluorescent antibodies to whole human immunoglobulin. Although 5\% non-inactivated serum did not restore the toxicity of $50 \%$ heat-inactivated serum, the marked suppression of toxicity by zymosan-A or mild heating suggests a dependence on complement [27].

The fluorescent staining results support previous reports of islet cell antibodies in diabetic patient serum [9-11]. In 3 of 6 cases surface staining of the dispersed mouse islet cells was observed; in one case staining was objectively proven by quantitative microscope fluorimetry. The $a b / o b$ mouse islets have more than $90 \%$ B-cells which, on dispersion, retain viability as judged from their morphology, secretory response to glucose, accumulation of $\mathrm{Rb}^{+}$, and exclusion of Trypan Blue $[13-15,28]$. The preparation could therefore be useful for extended studies of antibody binding to living B-cell surfaces. It is noteworthy, however, that the staining of mouse B-cells did not show a perfect correlation with the presence of islet cell antibodies diagnosed with frozen sections of human pancreas [11]. Larger series of patients and other functional tests are required to decide the frequency, nature and possible toxic effects of the stained antibody-like material. However, it is already clear that any adverse effect of islet-cell antibodies should be distinguished from the definite and very marked B-cytotoxic action of serum from both normal and diabetic man.

Cultures of islet explants are increasingly used for long-term studies of islet cells, although several factors still make it difficult to maintain normal function of the cells. Some authors prefer culturing in serum-free medium $[29,30]$, whereas others recommend the inclusion of serum [31-33]. Our results suggest that removal of complement by zymosan or mild heating may be worthwhile when culturing islets in serum-containing media. Fibroblasts are generally cultured with serum, but in contrast to islet cells they have been reported to exhibit enhanced $\mathrm{Rb}^{+}$uptake in response to serum [34].
Acknowledgement. This study was supported by the Swedish Medical Research Council $(12 \mathrm{x}-2288)$ and the Swedish Diabetes Association.

\section{References}

1. Gepts, W.: Pathologic anatomy of the pancreas in juvenile diabetes mellitus. Diabetes 14, 619-633 (1965)

2. Egeberg, J., Junker, K., Kromann, H., Nerup, J.: Autoimmune insulitis. Pathological findings in experimental animal models and juvenile diabetes mellitus. In: $\mathrm{O}$. O. Andersen, $\mathrm{T}$. Deckert, J. Nerup (eds.): Immunological Aspects of Diabetes Mellitus, p. 129. Copenhagen: Acta Endocrinol. 1975

3. Nerup, J., Andersen, O. O., Bendixen, G., Egeberg, J., Poulsen, J. E.: Antipancreatic cellular hypersensitivity in diabetes mellitus. Diabetes 20, 424-427 (1971)

4. MacCuish, A. C., Irvine, W. J.: Autoimmunological aspects of diabetes mellitus. Clinics in Endocrinology and Metabolism 4, 435-471 (1975)

5. Melin, K., Ursing, B.: Diabetes mellitus following mumps. Nord. Med. 60, 1715-1717 (1958)

6. Gamble, D. R., Taylor, K. W.: Seasonal incidence of diabetes mellitus. Br. Med. J. 1969 III, 631-633

7. Nerup, J., Platz, P., Andersen, O. O., Christy, M., Lyngsøe, J., Poulsen, J. E., Ryder, L. P., Nielsen, L. S., Thomsen, M., Svejgaard, A.: HL-A antigens and diabetes mellitus. Lancet 1974 II, 864-866

8. Cudworth, A. G., Woodrow, J. C.: HL-A system and diabetes mellitus. Diabetes 24, 345-349 (1975)

9. Bottazo, G. D., Florin-Christensen, A., Doniach, D.: Isletcell antibodies in diabetes mellitus with autoimmune polyendocrine deficiences. Lancet 1974 II, 1279-1282

10. Lendrum, R., Nelson, P. G., Pyke, D. A., Walker, G., Gamble, D. R.: Islet-cell, thyroid, and gastric autoantibodies in diabetic identical twins. Br. Med. J. 1976 I, 553-555

11. Christy, M., Nerup, J., Bottazzo, G. D., Doniach, D., Platz, R., Svejgaard, A., Ryder, L. P., Thomsen, M.: Association between HLA-B8 and autoimmunity in juvenile diabetes mellitus. Lancet 1976 II, 142-143

12. IdahI, L.-̊., Lernmark, $\AA$., Sehlin, J., Täljedal, I.-B. Alloxan $\beta$-cytotoxicity in vitro: Inhibition of rubidium pumping in pancreatic $\beta$-cells. Biochem. J. 162, 9-18 (1977)

13. Grankvist, K., Lernmark, А., Täljedal, I.-B.: Alloxan $\beta$ cytotoxicity in vitro: Microscope photometric analyses of trypanblue uptake by pancreatic islet cells in suspension. Biochem. J. 162, 19-24 (1977)

14. Lernmark, $\AA$.: The preparation of, and studies on, free cell suspensions from mouse pancreatic islets. Diabetologia 10, 431-438 (1974)

15. Lernmark, А., Sehlin, J., Täljedal, I.-B.: The use of dispersed pancreatic islet cells in measurements of transmembrane transport. Anal. Biochem. 63, 73-79 (1975)

16. Salk, J. E., Youngner, J. S., Ward, E. N.: Use of color change of phenol red as the indicator in titrating poliomyelitis virus as its antibody in a tissue culture system. Am. J. Hyg. 60, 214-230 (1954)

17. Sehlin, J., Täljedal, I.-B.: Transport of rubidium and sodium in pancreatic islets. J. Physiol. 242, 505-515 (1974)

18. Wigzell, $\mathrm{H}$.: Quantitative titrations of mouse $\mathrm{H}-2$ antibodies using ${ }^{51} \mathrm{Cr}$-labelled target cells. Transplantation 3, 423-431 (1965)

19. Heding, L. G.: A simplified radioimmunoassay method. In: L. Donato, G. Milhaud, G. Sirchis (eds.): Labelled Proteins in Tracer Studies, p. 345. Brussels: Euratom 1966

20. Täljedal, I.-B.: Interaction of $\mathrm{Na}^{+}$and $\mathrm{Mg}^{2+}$ with $\mathrm{Ca}^{2+}$ in 
pancreatic islets as visualized by chlorotetracycline fluorescence. Biochim. Biophys. Acta 372, 154-161 (1974)

21. Hellman, B., Sehlin, J., Söderberg, M., Täljedal, I.-B.: The mechanisms of action of chloromercuribenzene- $p$-sulphonic acid as insulin secretagogue: fluxes of calcium, sodium and rubidium in islets exposed to mercurial and a membrane-active antagonist. J. Physiol. 252, 701-712 (1975)

22. Bloom, G. D., Hellman, B., Idahl, L.-A., Lernmark, A.., Sehlin, J., Täljedal, I.-B.: Effects of mercurials on mammalian pancreatic $\beta$-cells: Insulin release, glucose transport, glucose oxidation, membrane permeability, and ultrastructure. Biochem. J. 129, 241-254 (1972)

23. Lacy, P. E., McDaniel, M. L., Fink, C. J., Roth, C.: Effect of methylxanthines on alloxan inhibition of insulin release. Diabetologia 11, 501-507 (1975)

24. Craighead, J. E.: Insulitis associated with viral infection. In: P. A. Bastenie, W. Gepts (eds.): Immunity and Autoimmunity in Diabetes Mellitus, p. 227. Amsterdam: Excerpta Medica 1974

25. Egeberg, J., Nerup, J., Andersen, O. O., Bendixen, G., Kromann, H., Gunnarsson, R., Hellerström, C., Poulsen, J. E.: Morphology of experimental, organ specific insulitis of the mouse pancreas. Acta Endocrinol. (Kbh.) 83, 133-150 (1976)

26. Freytag, G.: Do viruses serve as mediators of immunological reactions? In: P. A. Bastenie, W. Gepts (eds.): Immunity and Autoimmunity in Diabetes Mellitus, p. 247. Amsterdam: Excerpta Medica 1974

27. Kabat, E. A., Mayer, M. M.: Experimental immunochemistry, 2nd edition. Springfield: Charles C. Thomas Publisher 1967
28. Idahl. L.-^., Lernmark, A., Sehlin, J., Täljedal, I.-B.: The dynamics of insulin release from mouse pancreatic islet cells in suspension. Pfluegers Arch. 366, 185-188 (1976)

29. Buitrago, A., Gylfe, E., Hellman, B., Idahl, L.-Å., Johansson, M.: Function of microdissected pancreatic islets cultured in a chemically defined medium. I. Insulin content and release. Diabetologia 11, 535-540 (1975)

30. Frankel, B. J., Gylfe, E., Hellman, B., Idahl, L.-Å.: Maintenance of insulin release from pancreatic islets stored in the cold for up to 5 weeks. J. Clin. Invest. 57, 47-52 (1976)

31. Andersson, A.: Long-term effects of glucose on insulin release and glucose oxidation of mouse pancreatic islets maintained in tissue culture. Biochem. J. 140, 377-382 (1974)

32. Andersson, A.: Tissue culture of isolated pancreatic islets. In: O. O. Andersen, T. Deckert, J. Nerup (eds.): Immunological Aspects of Diabetes Mellitus, p. 283. Copenhagen: Acta Endocrinol. 1976

33. Goldman, H., Colle, E.: Human pancreatic islets in culture: effects of supplementing the medium with homologous and heterologous serum. Science 192, 1014-1016 (1976)

34. Rozengurt, E., Heppel, L. A.: Serum rapidly stimulates ouabain-sensitive ${ }^{86} \mathrm{Rb}^{+}$influx in quiescent $3 \mathrm{~T} 3$ cells. Proc. Natl. Acad. Sci. USA 72, 4492-4495 (1975)

Received: April 20, 1977, and in revised form.

August 5, 1977

Dr. Inge-Bert Täljedal

Department of Histology

University of Umeå

S-90187 Umeå 6

Sweden 